Please do not remove this page

RMIT

UNIVERSITY

\title{
Negotiating everyday life in Australia: unpacking the parallel society inhabited by Asian international students through their social networks and entertainment media use
}

Gomes, Catherine

https://researchrepository.rmit.edu.au/esploro/outputs/9921862224601341/filesAndLinks?institution=61RMIT_INST\&index=null

Gomes, C. (2015). Negotiating everyday life in Australia: unpacking the parallel society inhabited by Asian international students through their social networks and entertainment media use. Journal of Youth Studies, 18(4), 515-536. https://doi.org/10.1080/13676261.2014.992316

Document Version: Accepted Manuscript

Published Version: https://doi.org/10.1080/13676261.2014.992316

Repository homepage: https://researchrepository.rmit.edu.au

(c) 2014 Taylor \& Francis

Downloaded On 2023/04/27 00:35:59 +1000 
Thank you for downloading this document from the RMIT Research Repository.

The RMIT Research Repository is an open access database showcasing the research outputs of RMIT University researchers.

RMIT Research Repository: http://researchbank.rmit.edu.au/

\section{Citation: \\ Gomes, C 2015, 'Negotiating everyday life in Australia: unpacking the parallel society inhabited by Asian international students through their social networks and entertainment media use', Journal of Youth Studies, vol. 18, no. 4, pp. 515-536.}

See this record in the RMIT Research Repository at:

https://researchbank.rmit.edu.au/view/rmit:28982

Version: Accepted Manuscript

Copyright Statement:

(C) 2014 Taylor \& Francis

Link to Published Version:

https://researchbank.rmit.edu.au/view/rmit:28982 


\title{
Living in a Parallel Society: International Students in Australia and their Navigation of Everyday Life in
} Transience

\author{
Catherine Gomes ${ }^{1}$ \\ ${ }^{1}$ School of Media and Communication, RMIT University, Melbourne, Victoria, 3001, Australia \\ * Catherine Gomes: School of Media and Communication, RMIT University, Melbourne \\ Email: catherine.gomes@rmit.edu.au
}

\begin{abstract}
Work on the experiences of international students in Australia and elsewhere often point out that these students do not successfully integrate into their host society with many international students counting very few locals as friends by the time they complete their studies. The literature also highlights that the transient migrant experience would be more positive if international students counted locals as friends. Through in-depth interviews with 47 Melbourne-based higher education international students from Asia — the source of Australia's largest export education market - this study uncovers the reasons why these students have very few or no local friends and how they navigate a workable everyday experience in their host nation. The findings suggest that Asian international students live in a parallel society almost exclusively made up of fellow international students who primarily come from the home nation, the Asian region and elsewhere. This parallel society allows international students to create a sense of community in Australia while at the same time being detached from local society. This disconnection is fostered by a lack of engagement in Australian culture due to an almost complete lack of consumption of local entertainment media. By investigating their social networks (society) together with their consumption of entertainment media (culture), this study presents an indirect yet creative way of understanding how international students negotiate everyday life as transient migrants in the Australian city of Melbourne. Doing so, this paper highlights the ways in which international students make use of their social networks and their entertainment media to navigate a workable experience in a foreign country.
\end{abstract}

Keywords: Asian international students, social networks, community, disengagement, media consumption

\section{Introduction}

In 2013 I interviewed Asian international students in Australia for a cross-disciplinary project that looked at their self-perceived identities, social networks and media consumption. Bringing together these three elements was a creative way of examining the everyday life of international students as they lived in transience for the duration of their respective courses. I found that the students I spoke to lived very much in a parallel society made up almost exclusively of other international students. These students' networks were made up of students from their home nations as well as from neighbouring Asian regions, and occasionally from other countries. Living in this parallel society meant that these students were disconnected from Australian society and culture. 
This disconnection took place despite Australia being a multicultural nation with a rich and diverse settler history and heritage.

Asian-born international students have had a presence in Australia ever since the commencement of the Colombo Plan in 1951 when soon-to-be decolonised nations and former colonies in the British Commonwealth sent sponsored students to be trained in skills that would assist in the economic, infrastructural and social development of these nations. By the 1980s, Australia became a global player in the export of education in the region by offering courses and qualifications which attracted students from Southeast Asia and, increasingly, from Northeast and South Asia. In 2010-11, education services brought in AUD\$16.3 billion through full-fee paying international students. ${ }^{1}$ By the end of 2013 there were 526,932 international students enrolled in educational institutions throughout Australia (AEI 2013a). Most of these students came from a range of different countries from Asia, the Middle East and elsewhere. However, the majority of international students came from Asia, with the top countries being China (118,832), India (37,041), Republic of Korea $(20,778)$, Malaysia $(19,653)$ and Vietnam $(17,861)$ (AEI 2013b). While there are also high school-going international students in Australia, their numbers are not comparable to those who are undertaking post-secondary study in universities, vocational education and training (VET) institutes and English Language Intensive Courses for Overseas Students (ELICOS) colleges ${ }^{2}$. Combined, all sectors excluding schools make up 96.6 per cent of the market share (AEI 2013a). International students today inhabit Australian cities and towns, supporting higher education institutions and high schools.

International students in higher education further contribute to the Australian economy through casual and seasonal employment. As a condition of their visa, international students are not allowed to hold full-time permanent jobs, since that would require a separate working visa. International students, however, are allowed to work a total of 40 hours per fortnight (Department of Immigration and Border Protection 2014). This means that they usually work part-time in contract or non-contract positions. International students often work in retail, hospitality, tourism, agriculture (e.g. fruit-picking), sales and telemarketing, administration or tutoring. Postgraduate international students, particularly doctoral candidates, often take on sessional tutoring jobs at universities (ATC 2014). In 2009-2010 the median weekly income of students in employment was \$564 (ABS 2013). International students work primarily to support themselves since international student fees are high. The Australian government estimates that in 2014, an undergraduate degree cost between AUD\$15,000 and 
AUD\$33,000, a postgraduate Masters degree between AUD\$20,000 and AUD\$37,000, and a doctoral degree between AUD\$14,000 and AUD\$37,000 (ATC 2014). Meanwhile, the estimated cost of living in a shared student apartment in the city of Melbourne is AUD\$23,400 to AUD\$30,500 per annum (Student Services, The University of Melbourne 2014).

In the meantime, 1 in 5 (22\%) of all tertiary students were international students with New South Wales and Victoria supporting the most number of students, with a combined share of $58 \%$ of the entire Australian market (ABS 2011). Fifty-five per cent of the combined New South Wales and Victorian international student population live and study in Melbourne alone (City of Melbourne 2013). These international students attend the universities, VET institutes and ELICOS colleges within the city and occupy residential apartments in the heart of the CBD.

While international students come from diverse backgrounds and are visible actors who play an instrumental part in the Australian economy as consumers and service providers, because they are transient, they are generally not included in broader discussions on Australian society, culture and multiculturalism. In part this could be because studies on international students tend to focus on the siloed issues of international student recruitment, international study, and international student health and well-being. ${ }^{3}$ Increasingly though, work on international students highlights the difficulties students encounter within the society and culture of the host nation. Here, the literature often points out that many students do not feel to be a cohesive part of Australian society. In other words, the international student experience is often marred by the lack of local friends these students have by the end of their course of study. This occurs in Australia despite a multicultural population where many citizens are born in Asia and other nations (ABS 2012). Moreover, some Asian international students are familiar with diversity, coming from nations that are increasingly multicultural, multiethnic and multilingual such as students from Singapore and Malaysia. How then do international students create a sensible and workable existence in Australia if they are not integrating into (multicultural) Australian society via friendships with locals?

\section{Methodology}

Armed with this question, I interviewed 47 Asian international students studying at higher institutions in the city of Melbourne. Table 1 provides a demographic breakdown of the students. It shows that more women than 
men took part in this study even though only $47.6 \%$ of international students are women in Australia. This incongruence could possibly be because gender distribution varies depending on which countries the students come from. For instance, there are more female international students in Australia from China (51.8\%) and Vietnam (51.9\%) (AEI 2013a). The table also shows a high number of students under 25, which correlates with the overall demographics of international students in Australia where $46.3 \%$ of students are in this cohort (AEI 2013b). Table 1 also shows that international students pursue a variety of diploma/degree programs across a wide cross-section of disciplines and come from a range of countries in Asia. It also indicates that most participants have been studying in Australia for more than a year, while half work part-time.

Table 1.

\begin{tabular}{|c|c|}
\hline Gender & $\begin{array}{l}\text { M (18) } \\
F(29)\end{array}$ \\
\hline Age Range & $\begin{array}{l}19 \text { to } 24 \text { yes (28) } \\
25 \text { to } 29 \text { yrs (15) } \\
30 \text { yes and more }(4)\end{array}$ \\
\hline Education Pursuit & $\begin{array}{l}\text { Diploma \& Advanced Diploma (8) } \\
\text { Bachelor degree (19) } \\
\text { Masters degree \& higher (20) }\end{array}$ \\
\hline Discipline Areas & $\begin{array}{l}\text { Accountancy (2) } \\
\text { Arts (3) } \\
\text { Aviation (1) } \\
\text { Biomedicine (1) } \\
\text { Business (2) } \\
\text { Commerce (6) } \\
\text { Communication (1) } \\
\text { Computer Science (1) } \\
\text { Engineering (1) } \\
\text { Environment (1) } \\
\text { Event Management (1) } \\
\text { Finance (1) } \\
\text { Law (1) } \\
\text { Medicine (1) } \\
\text { MBA (1) } \\
\text { Science (1) } \\
\text { Social Work (1) } \\
\text { Translation (1) } \\
\text { Unclassified (20) }\end{array}$ \\
\hline Home Country & $\begin{array}{l}\text { Bangladesh (2) } \\
\text { China (8) } \\
\text { India (6) } \\
\text { Indonesia (3) } \\
\text { Japan (1) } \\
\text { South Korea (4) } \\
\text { Malaysia (5) } \\
\text { Pakistan (3) } \\
\text { Singapore (8) } \\
\text { Vietnam (6) } \\
\text { New Zealand, originally China (1) }\end{array}$ \\
\hline $\begin{array}{l}\text { Length of stay in Australia at time of } \\
\text { interview }\end{array}$ & $\begin{array}{l}3 \text { mths (3) } \\
3.1 \text { to } 6 \text { mths (5) }\end{array}$ \\
\hline
\end{tabular}




\begin{tabular}{|l|l|}
\hline & $6.1 \mathrm{mths}$ to $1 \mathrm{yr}(7)$ \\
& $1 \mathrm{yr} 1 \mathrm{mth}$ to 2 yrs (15) \\
& 2 yrs 1mth to 3 yrs (7) \\
& 3 yrs 1 mth to 4 yrs (8) \\
& 4 yrs 1 mth and more (3) \\
\hline Part-time work & Yes (22) \\
\hline Intention to apply for Permanent Migration & Yes (18) \\
\hline
\end{tabular}

Around $30 \%$ of the participants had the intention of or open to applying for permanent migration. As one male undergraduate student from Indonesia explains:

Yeah I would consider PR too. It depends if I get a job or not in here....if I don’t get [a job] it's not the end of the world so I can still go back to my own country.

While the student is realistic about his future in Australia, the desire for permanent residence is obvious. This is not surprising since increasing numbers of international students in general have the intention of making their stay permanent and contributing to the workforce. In 2010, a JWT Education survey of 1600 international students revealed that 22\% intended to apply for permanent residency (Harrison 2010). More recently, Robertson (2013) has argued that international students are not merely in Australia to study but rather to invest their time and energy into securing permanent residence. Clearly international students look at Australia not solely as a study destination but as a place for their future.

The students whom I interviewed were also part of a larger international study on transient migrants with fieldwork conducted from early 2013 to mid-2014. The findings revealed that international students form a parallel society made up of fellow international students that has no clear connections to (multicultural) Australian society or culture. When I discuss the term “society” in this paper, I have in mind Anthony Giddens' (1981) assertion that a society is made up social systems which are not necessarily limited to national boundaries, and also John Urry's (2000) prediction that globalisation has destabilised the once autonomous territorially defined societies. Australian society in this sense is made up of international students and communities of international students whose social networks are firmly based on their identity as foreign students studying in Australia. While they maintain their own national identities, it is their identity as international students that dominate their sojourn in Australia. This is because international students create a sense of (transient and communal) identity for themselves as foreign students in Australia, while creating social networks that are largely made up of fellow international students, mostly from their home country or region.. 
The reasons for the constitution of this society are not just due to cultural similarity or familiarity, but to their common experiences as foreign students living and studying in Australia, an experience which they feel can only be understood by other international students. This unique international student experience however can become an unfortunate barrier for integration into Australian (multicultural) society.

This disengagement from Australian society and culture is compounded by international students' media consumption, in the sense that they are not being exposed to a version, real or imagined, of Australian culture. International students almost never watch Australian-made television programs or films nor listen to Australian radio. Instead, they watch and listen to the same entertainment programs as they did in their home nation because of online accessibility and availability. Other than content from their homeland, students also consume media from the USA. So unlike audience studies literature (Morley 1980; Davis and Baron 1981; Moores 1993), which often argues that media shapes culture and therefore society in this case because international students do not experience Australian culture, they may not be influenced by it nor identify with it. While local students perhaps may themselves watch and listen to American productions, the difference between local and foreign students is language. English is the official language in Australia and the language used in American productions. With the exception of Singapore, English however is not the official language in Asian nations. Before Ii discuss the findings of this study, I want to look at Australian multiculturalism and the place it holds (or does not hold) for international students.

\section{Australian Multiculturalism and the Missing International Student}

Australia is a country of migrants. Twenty-six percent of Australia’s citizens and permanent residents are born overseas (ABS 2014). Most of these migrants come from the United Kingdom, New Zealand, China, India, Vietnam, Italy, the Philippines, South Africa, Malaysia, Germany, Greece, Sri Lanka, the United States of America, Lebanon and the Netherlands, and often live in urban areas, particularly in capital cities. The most popular destinations for migrants are Sydney, Melbourne and Perth. In Melbourne, 35\% of its population are born overseas (ABS 2014). Because of its strong migrant population, Australia has put in place an official multicultural policy that 'embraces...[its]...shared values and cultural traditions' which allows people to 'celebrate, practise and maintain their cultural traditions within the law and free from discrimination'. The aim of the policy is to 'strengthen social cohesion through promoting belonging, respecting diversity and fostering engagement with Australian values, identity and citizenship, within the framework of Australian law' 
(Department of Social Services 2014). As a result of this policy, both federal and state governments have created various settlement and migrant education programs, migrant organisations (Australian Multicultural Council), commemorative events (Harmony Day), as well as laws against racial vilification. Australia also has the Special Broadcasting Service (SBS), a dedicated free-to-air publicly funded television and radio network supporting multilingual and multicultural programing.

While Australian multiculturalism is a part of everyday life, Australia has still experienced echoes of its racist past over the last 20 years, with the rise of political parties such as Pauline Hanson's One Nation and Daniel Nalliah’s Rise Up Australia Party taking definitive stands against migration ${ }^{4}$. Furthermore, during federal elections, debates on the benefits of multiculturalism are often discussed as a hot button issue, with the major parties taking more conservative stands. These issues often involve limiting migration and concerns that new migrants cannot/will not assimilate and that they will be a burden on the economy. In addition, Australia has experienced very public racial tensions, such as the 2005 Cronulla Beach Riots, which saw young AngloAustralian and Lebanese-Australian men inflict violence on each other in racially motivated attacks. While large scale racial riots are not commonplace in Australia, there has been an increase in media reports of incidences of racial vilification on public transport in capital cities and aggressive displays of the Australian flag. The Australian flag has been used by individuals and racially-charged groups as a symbol for displaying their nationalist and Anglo heritage yet anti-immigration and anti-multicultural sentiments (Fozdar, Spittles \& Hartley 2014).

Where there have been some significant challenges to Australian multiculturalism, commentators such as Ali Rattansi (2011) are generally of the opinion that Australian multiculturalism has been a success when compared to European multiculturalism. Rattansi $(2011,18)$ states 'the conception of a positively multiethnic, multiculturalist nation has been fostered as an identity for the whole nation'. Meanwhile, Australia's current Race Discrimination Commissioner Tim Soutphommasane explains in Don't Go Back Where You Came From (2012) that multiculturalism in Australia has indeed worked despite the racism and the politicising of immigration and asylum seekers by politicians and the media. This Australian multicultural identity has also allowed for public and intellectual debates and discussions by politicians and scholars alike. When he was Opposition Leader in 1988, the future Prime Minister of Australia John Howard (1997 - 2007) released a document calling for an end to multiculturalism called the One Australia policy. Prominent historian Geoffrey 
Blainey came under heavy criticism for publishing works in the 1980s that warned of the social, cultural and economic ill effects of increased Asian immigration into Australia (Ryan 2005).

Discussions on multiculturalism in Australia, however, often centre on citizens and permanent migrants. ${ }^{5}$ This is demonstrated in the omission of any reference to international students in the agenda, policy or literature of government bodies such as the Australian Council of Multiculturalism or the Victorian Multicultural Commission . The only time in the recent memory when international students were part of this discussion was during the media frenzy surrounding the number of Indian students being violently attacked, primarily in Melbourne, and the organised Indian student protests that followed (Koleth 2010). On the one hand this is not surprising, since international students are transient and here because of the financial agreement they have not only with the education sector but with other related (e.g. realty) and indirectly related sectors (e.g. tourism) that service these students. On the other hand,omitting international students from national conversations about multiculturalism risks limiting the national perspective of these students as mere transient sources of foreign revenue.

International students from Asia may have similar ethnic and cultural roots as Asian-Australians but this does not necessarily mean that these groups identify with each other or that they form strong social ties. Gomes (2014) suggests that in multicultural Singapore - a country where Singaporeans of Chinese and Indian backgrounds are the dominant ethnicities - there is tension between Singaporean citizens and migrants because citizens view new migrants as different to them, despite the fact that Singaporean citizens may themselves have a similar migrant heritage. Their cultural experiences as Singaporean-born citizens have evolved differently to those who are ethnically similar to them due to historical differences, for example. Time and place, in other words, affects the development of the cultures of ethnic communities despite similar roots.

International students not only contribute to the Australian economy but also provide Australia with the opportunity for direct access to understanding Asia(ns). Additionally, a quarter of international students (Harrison 2010) want to stay in Australia as permanent residents and/or citizens, thus contributing to the continuing Australian migrant and multicultural story. Understanding international students in broader discussions of multiculturalism and migration would allow for Australia to develop dynamic strategies for understanding Asian cultures. This is because while many international students are from Asia, they may not 
blend in with established multigenerational (Asian) migrant communities. They are, as Chau (2010, 17 ) puts forward, possibly ‘a new and emerging community' unto themselves. Findings from my study show that international students create communities with other international students through their social networks which are strongly based on cultural (home and region) affiliation. I conclude that they appear to form a parallel society within Australia.

\section{Implication of Social Networks for International Students}

Work in the area of international students in Australia and the USA often highlights the significance of social networks for international students. The contribution of friendship to the happiness, well-being, acculturation and social stability of international students is well acknowledged by researchers (Kudo \& Simkin 2003; Ying 2002; Gomes \& Alzougool 2013; Gomes, Berry, Alzougool \& Chang 2014). Literature has shown that international students’ social networks mostly consist of other international students (Kashima \& Loh 2006; Kashima \& Pillai 2011). The literature also notes that international while international students form friendships with individuals from their own country, from other countries, and from the host country, international students often have more friends who are are fellow citizens from the home country living (and studying) in the same host country. Portes and DeWind (2004) found that international students in the U.S.A formed friendships primarily with other foreigners, citing differences between American and their own experiences as foreigners as the reason for their lack of integration.

Research has also demonstrated a correlation between having more host country friends and feelings of satisfaction, contentment, decreased homesickness, and social connectedness. Hendrickson, Rosen and Aune (2011) analysed the relationships between social networks, social connectedness, homesickness and satisfaction levels of international students, by examining the friendship network ratios, strength, and variability within three friendship groups of 86 international students in the University of Hawai'i. A friendship network grid was developed to assess where international students’ friends were from and how strong those friendships were. International students with a higher ratio of friends from the host country in their network claimed to be more satisfied, content, and less homesick. Furthermore, participants who reported more friendship variability with host country individuals described themselves as more satisfied, content, and more socially connected. This correlates with Sawir et al.’s (2008) earlier Australian study that argued for more social interactions between international students and people from outside the home nation, as a successful way of curbing loneliness. They 
suggested that international students who formed friendships with nationals from the home nation were more lonely than those who broadened their social networks to include people from the host nation or international students from other countries. Clearly social networks are significant for international students when it comes to having a healthy and positive international student experience in their host nation and for becoming comfortable in the host society. The literature highlights two salient points: that international students form friendships with fellow international students and that these students are largely from the home nation. In the next section, I will suggest that international students make friends with other international students because this is how they identify themselves while in transience and that this creates a distinctive community with specific experiences and needs. I also argue that while Asian international students in this study may form friendships with fellow international students from their home country, there is an increasing trend of international students widening their social circles to include individuals from the region. In addition, forming friendships with fellow international students rather than locals is based on practical reasons that assist in day-to-day living in Australia which respondents felt locals have limited knowledge of such as opening a bank account as an international student.

\section{Community and Transience: Identifying as International Students}

During my 2013 study on international student identity, I interviewed 47 participants who all identified themselves as international students studying in Melbourne, Australia. While the students I spoke to acknowledged that their nationality was significant to them and not easily erased or hidden, it was their distinctive identity as international students that created a strong sense of identity for them while studying in Australia. Their identification as international students, in other words, was an additional identity for them. A male postgraduate student from Pakistan elaborates:

For me I preferred to be called as a student, like international student if we talk about it especially in Australia or like a country there.

His identifying as an international student is not surprising since being foreigners studying over a specified period of time is the very reason for their presence in Australia. Likewise being officially labelled as an international student allows international students to be part of an identifiable collective. International students often identify themselves according to their visa status, which provides a sense of belonging through a created (transient) community. Their status as foreign students provides them with an almost immediate community 
which they can identify with and feel a sense of belonging to, particularly through cultural similarity and familiarity, as well as common shared experiences of living as foreigners in Australia.

Arjun Appadurai (1996) correctly notes that the global cultural flows and circulation of people, finances, technologies, media and ideas have created new collectives and thus identities. However, these new collectives are also unique as they become what Benedict Anderson (1983) calls imagined communities which exist outside their geographical and national boundaries. While Anderson specifically looks at how communities maintain their national and cultural identities outside their homelands, his template allows us to build upon his theory of the imagined community in order to unpack the complex identities which are evolving for international students, as part of the globalisation process. Manuel Castells (2009) suggests that identity is evolved which suggests that identity formation is an ongoing process. Global flows such as the movements of people 'can disrupt a sense of belonging to community but create new forms of connectivity and can allow for new kinds of spatial configurations' (Nadarajah, Mulligan, Singh \& Chamberlain 2014, 17). The global movements of people in other words, while disruptive, are also creative in the sense that they allow individuals more freedom to form new communities according to their needs. Nadarajah et. al. $(2014,16)$ further explain that the global movements of people has 'actually increased the desire for community precisely because people are obliged to make a more conscious effort to find community in the midst of such complexity'. Referring to the work of Gerard Delanty $(2003,130)$ Nadarajah et. al. state that 'very few people are now born into communities that have a fixed and well defined identity. This means that a sense of belonging to community needs to be 'wilfully constructed" $(2014,16)$. Since a community is made up of individuals who bring with them their own social networks, it is of no surprise that international students in this study gravitate towards other international students, particularly those from the same country and region.

Drawing on Giddens' (1991) theorisation that an individual's identity is not merely based on past experience but is an ongoing narrative, this paper asserts that international students create a sense of identity for themselves based on their transient experience in order to form a community of needs. This community of needs is dynamic, empowering yet exclusive, because it allows international students to be linked to the culture and people of their home nation/region while at the same time also connected to their host nation but on their own terms. Making friends with fellow Asian international students thus provides a sense of familiarity in the wake of the trauma of being (voluntarily) uprooted while at the same time contributing to their ongoing narrative in 
transience as they navigate their shared experiences as transients in Australia. While the narrative of transience is not specific to Australia but to the international student community in Australia, the international student experience becomes a clear yet parallel narrative in the Australian everyday story. This narrative becomes a signifier for the parallel society international students in Australia form.

\section{Social Networks are International Student Networks}

All participants in my study revealed that they form social networks with other international students they meet in Australia. Participants explained that they made friends with other international students they met at their current institution and in the courses they undertake in that institution. Some noted that the courses they attend are significantly populated by other international students. Others explained that they usually sit next to fellow international students at lectures and tutorials and hence get to make friends this way. Students explained that only Asian international students tend to take the front seats during lectures and tutorials so this becomes an incidental way of getting to know other international students. Around half of the participants came from nonEnglish speaking backgrounds and were currently enrolled in or had previously completed English-language courses in Australia. These students reflected that that they also maintained friendships with students they meet there. ${ }^{6}$ Participants also made friends with other international students outside the campus environment. Sources of these friends included people who shared similar hobbies (e.g. photography);participated in sporting groups (e.g. soccer and cricket) with them; were from their workplace or volunteer group; were members of the same religious associations or places of worship such as churches and mosques; were from their local neighbourhood; or were friends of friends.

Participants also noted that while a number of their international student friends came from their respective homelands, they also expanded their social networks to include international students from around the Asian region. The students noted that while they were open to making friends with other international students not from the Asian region, in order to learn new cultures, they were more cautious when doing so with only a handful of students in this position. So why do Asian international students look for other Asian international students in Australia? The students I spoke to generally felt that it was easier to make friends with other Asians because of cultural familiarity and similarity and because of a shared experience as foreign students with specific needs while living in transience. 
International students, as Hendrickson, Rosen and Aune(2011) have noted, are comfortable not only with fellow international students from their home but also with international students from their region and sometimes from other regions. International students identify and bond together as a community precisely because of their status as foreigners living and studying in Australia for the duration of their course of study. Most often, they make friends with other international students they meet in obvious places such as their courses. The participants in my study felt that only other international students were able to understand the issues they were going through while living overseas, such as the emotional factors of being away from home (homesickness) and the practical issues connected with living in Australia (e.g. finding suitable accommodation in terms of affordability, safety and nearness to campus). While the participants in this project were also connected to their friends still residing in the home nation and kept in contact with them via telephone and social media, having other international students as friends allowed participants to fill the huge gap that had been left because of their separation from not only their homeland but more significantly from family and friends (Kudo \& Simkin 2003; Ying 2002; Kashima \& Loh 2006; Kashima \& Pillai 2011; Gomes \& Alzougool 2013; Gomes, Berry Alzougool \& Chang 2014).

\section{Like Attracts Like: Looking for Other International Students}

All participants expressed the importance of having friends during their sojourn in Australia. Some of these reasons unsurprisingly point to international students wanting to make friends with people in Australia (but not necessarily Australians) as a coping strategy for being away from their homeland. A way participants accomplished this was to actively look for people in Australia who shared similar cultural or language backgrounds. Participants expressed that identifying as Asian and being friends with other Asians provided them with a sense of community due to similarities in cultures (e.g. Singaporeans and Malaysians are familiar with each other's cultures due to their geographical and cultural proximity, and a shared history as former British colonies).

Participants noted that it was their Asian international student friends, particularly those from their own homeland, who were able to provide the most comfort and support,because of a similar culture or language. The following female undergraduate from Singapore, for instance, expresses the importance of having friends from the home nation in Australia: 
[W]hen I'm here, I don’t really feel that homesick, because like he said, most of my friends are Singaporean and ...[I]....stay with the Singaporean. So I'm mostly surrounding by .... [Singaporeans] ... and ..., so yeah, I don't feel that out of place or anything.

For this student, having Singaporean friends provided her with a sense of belonging because her friends not only reminded her of home but were a connection to home. What is more, her domestic environment - the members of her household - was Singaporean. Her Singaporean friends and housemates allow the challenges of being uprooted from the homeland to be bearable since she is not only immersed in a Singaporean (diasporic) community but one that shares her specific experience as a Singaporean student in Australia.

The students I spoke to also highlighted the significance of language as a primary source for commonality and comfort. Castells (1997) perhaps puts it best when he recognises that 'language, and particularly a fully developed language, is a fundamental attribute of self-recognition, and of the establishment of an invisible national boundary less arbitrary than territoriality, and less exclusive than ethnicity’ (52). So an ethnic Chinese student from Malaysia is able to find commonality with an ethnic Chinese student from Singapore because both students understand a creolised form of English spoken in their respective homelands that blends English with the other local languages (e.g., Bahasa Malaysia, Chinese dialects such as Hokkien and Cantonese, and Tamil). ${ }^{7}$ Students from China whose native language is Mandarin are also able to find comfort from speaking their native tongue with others such as the diasporic Chinese in Asia (e.g. Singaporean Chinese and Malaysian Chinese). As a female undergraduate from China explains:

For me, it's like, you make friends that are similar to your language or the way you speak, because then you feel more at home.

This student thus would feel more 'at home' with others who spoke Mandarin but not necessarily with those who come from China. Southeast Asian nations such as Singapore, Malaysia and Indonesia have significant Chinese diasporic populations with Singapore in particular supporting an ethnic Chinese demographic that is around three quarters of its citizenship. More significantly, Mandarin is a widely taught language in the Singaporean school system (kindergarten to high school) and is compulsory learning for all ethnic ChineseSingaporeans. Students from China are able to communicate easily with Singaporean-Chinese students in Mandarin. A male Singaporean undergraduate clarifies: 
[W]hen you speak to everyone, you can convey a message - you don’t have to worry about the language they use and everyone around you speaks the same. It will be in Mandarin ... so for me, I guess when I speak to people and they sound the same, that's how I feel, like I'm at home.

Conversely, international students from non-English speaking backgrounds explained that speaking in English sociallycaused them great stress. This is one of the major reasons why they prefer to converse in their native language, as explained by a Korean female postgraduate:

Yes and I could see my other friends, like Taiwanese or other Chinese, I also feel very stressful to talk with local students because their speaking is very fast and they, even they, I think even they can't guess which words we can't get it, because they haven't been in, like a situation, they are natural English speaker. So when, even when I ask, “I don’t get it can you explain it”, they try to explain again but they ... what is it, that situation is, seem a little bit embarrassed I think to them because they haven't been situated.

The above participant expresses the pain of embarrassment she feels when she speaks English to Englishspeaking Australians. She is aware of her limitations in the language and chooses not to get into what she imagines to be confronting situations with Australians. It is easier and less distressing for her to mix with other Asian international students even though they do not share a common native language - Korean is her first language while Mandarin is most likely the mother tongue of her Taiwanese and Chinese friends. However, is language the only reason for mixing with international students?

In their study of international students in the United States, Portes and DeWind (2004) found that international students in the U.S. felt that Americans did not understand their experiences as foreigners, while they could not relate to American culture such as interests in sports. As noted by Hendrickson, Rosen and Aune (2011), international students are not only comfortable with fellow international students from their home but also with international students from their region and sometimes elsewhere. Likewise, participants in this study also maintained that they made friends with fellow Asian international students and sometimes elsewhere for practical reasons. They rationalised that they were able to connect and identify more with non-locals because of similar and shared experiences of being foreigner students. For instance, some participants note that when they come to Australia they actively seek fellow international students from their home nation, Asian region and sometimes elsewhere to help them adjust to Australia. Turning to fellow international students for advice and help comes about because participants believe that these friends would have gone through the same issues they 
face and hence they are able to advise these friends accordingly. As a female postgraduate student from Indonesia succinctly explains:

I meet the same people, with the same condition as me, I mean they're international students from Asia or from Africa, from ... I think even though I feel upset, that I don’t meet any Australian, but then I become like - with the group of people, that at least we have the same experience, even though we're from different countries. But then, I come to my university at ..., that I find some of wonderful friends from Indonesia, I think they help me a lot, especially to deal with the accommodation and sort of things. Because there is some consideration for me, myself, to think, where should I live?...Because we have the same interests, that makes our bonds stronger.

While she obviously would like to make friends with locals, to this student, fellow international students provide her with the greatest support in her everyday life in Australia. Moreover, she states that she is attracted to international student friends and acknowledges the unique assistance they provide. Unsurprisingly, the general reason she does not have any local friends is because of a lack opportunity, which correlates with what was raised earlier in this paper about international students and the places where they meet fellow internationals students (e.g. when sitting in the front at lectures and tutorials).

Some participants think that locals will not be able to provide advice that is specific to international students primarily because they do not have similar experiences as foreign students. As the following male student from China, who is undertaking an associate degree, explains:

Yes same culture, same, because I can share some information with them, we can help each other. Because international students recognise these kind of needs, we can easily get to be friends I think rather than ... [with local] ... student.

It is apparent from the above sentiments expressed by this student that not only are there are clear benefits from being friends with fellow international students but this friendship takes place organically. Additionally he notes that this is not a one-sided affair where there seems to be a certain code of behaviour where international students are mutually beneficial towards each other precisely because of their shared experience as foreign students. Participants, in other words, generally felt that turning to fellow international students from the same country is a necessary avenue when it comes to advice on living as foreign students in Australia thus allowing for their parallel society to flourish. Clearly there are benefits in becoming friends with fellow internationals. However, does doing so hinder international students from becoming integrated or assimilated into Australian society? In other words, do the very motives that instigate international students to become friends with each other the same reasons why they are not friends with locals? 


\section{Identifying as International Students Prevents Friendships with Locals}

Perhaps the most troubling response from participants about their social networks in Australia was the lack of connections they had with the local population even though most had been in Australia for more than a year. Almost all participants declared that they would like to make friends with Australians; however, only 5 out of the 47 participants said that half or more of their friends were Australian. Those who did count Australians as friends noted that they had to actively get to know locals while at the same time developing and maintaining relationships with other international students. Generally participants said that they either had very few Australian friends or had no Australian friends whatsoever. When I asked some participants who they considered “Australian”, the answer most gave was “Caucasian” or "white”. The participants' notion of the Australian local population being white is not surprising since the dominant discourse in Australia is based on Australia as a former British colony (Hage 1998;Stratton 1999) and its local entertainment and news media strongly dominated by “white” faces (Jakubowicz \& Seneviratne 1996).

It is possible, however, that the understanding of Caucasian/white may be different in Asia where the term(s) are not restricted to anyone who vaguely looks blonde and/or blue-eyed and has pale skin. In Singapore for instance, the often-used terms ang moh and gweilo are used to describe anyone who Singaporeans classify as Caucasian or white which are generally people who do not look clearly Asian or African. ${ }^{8}$ A person who is deemed Hispanic in the Americas for instance, might be considered Caucasian/white in Singapore since they do not look specifically Asian or African. The (mis)understanding of Caucasian/white is part of everyday life in Singapore that it is reflected in the media. In the popular Singaporean television comedy show The Noose (2007-present), Barbarella, played by Michelle Chong, often refers to her 'American amg moh boyfriend Eduardo' who is implied to be Eduardo Saverin, the Brazilian-born former U.S. citizen and co-founder of Facebook, who lives Singapore. Saverin in other words, would be widely accepted to be Caucasian/white by Singaporeans.

Interpreting Australia as dominated by Caucasian/white people is an attraction for international students enrolling in courses there. A "white" Australia rather than a multicultural Australia becomes a desirable destination for students who interpret studying in a Western (white) nation as adding to their social capital. Whiteness becomes a signifier of cultural and social power so much so that whiteness by association is sought- 
after. Many Chinese students, for example, view studying overseas in the West, primarily in the United States, as desirable (Yang 2014). A female Chinese undergraduate for instance, informed me that she would have not come to Australia 'if it was filled with Asians'. She saw nothing advantageous about Australia otherwise. However, she did not experience intra-ethnic othering (Abelmann 2009, 162) since her social circles in Australia were almost exclusively made up of other (Chinese) international students.

When I queried participants about what they thought of Asian-Australians (Asians who were either born or raised in Australia) as a grouping and if they had friends who are in this group, the answers were varied. The term Asian-Australian itself received some diverse responses as some participants understood members of this group to be loosely grouped Australian-Born-Chinese (ABCs), while others thought they were Asian-born permanent residents. Those who said that they were friends with Asian-born permanent residents noted that these were recent migrants whom they consider more culturally similar since they were more Asian than Australian. Participants explained they generally did not have Asian-Australian friends since they believed that Asian-Australians desired only to be friends with white/Caucasian Australian and not with Asian international students. They also commented that they did not have much in common with Asian-Australians because they felt that Asian-Australians had more in common with white Australians than they did with Asian international students. So while Asian international students may be ethnically, and in some ways culturally, similar to Asian-Australians, both groups have evolved distinct cultural identities.

The participants generally stated that while they would like to be friends with Australians they felt that there were barriers to this taking place. These barriers are connected to cultural differences and language, together with the lack of cultural interest by local students which sometimes borders on racism. The inability of international students to speak English 'properly', as raised earlier in this paper, being the most often cited as reasons for the lack of interaction by international students. Several participants reflected on their lack of social interactions with local students:

I just have a feeling like they don’t really want to make friends with international students. I guess of the main reasons because of my broken English because I cannot talk with them. Sometimes I keeping asking them to repeat and repeat and they get frustrated and they don't want to get further into a friendship with me [Student 1: M/Ugrad/Vietnam] 
I feel like students, local students don't really mix much with Asian, except for local Asians they will mix around, but not Asian-Asian [Student 2: F/Ugrad/Singapore]

[B]asically I think Australian people don't think of other people from other things; this because they have a language difference - their accent different and they kind of prefer people from an Australian accent [Student 3: F/Ugrad/Malaysia]

All three students revealed not only a desire to make friends with locals but also a sad resignation as to why Australians do not want to be friends with them. They felt that their lack of English skills had resulted in them not being able to develop any meaningful relationships with Australians. In addition, they pointed out that while Australians were often friends with Asian-Australians, they are not interested in knowing Asian international students predominantly because they had next to nothing in common with them. So according to the participants, the very reasons why international students are interested in each other are also the very reasons why local students are not interested in them.

However, a few participants in this study stated that they were the ones who needed to adapt and change in order to get to know locals. For instance, participants who did have local (white) friends stated that they were proactive in getting to know Australians. They also verbalised that circumstance (e.g. living in dormitories) allowed for greater opportunities to get to know Australians. Besides, while researchers often point out that language is the main barrier for the formation of intercultural relationships with members of the host nation (Gudykunst et al. 1991; Yamazaki, Taira, Shun-ya \& Yokoyama. 1997; Kudo \& Simkin 2003), participants in this study expressed a strong desire to improve their English-speaking skills so that they would be able to make friends with locals.

While many international students surround themselves with people of similar experiences and cultures, while remaining disengaged from Australian society, is this also the case with their consumption of entertainment media or are they open to Australian media productions in order to learn more about their host nation?

\section{Entertainment Media: Connections to Home and Disconnections in Australia}

The expansion of mobile, web applications and social media have dramatically altered the way subjects network, particularly the way in which international students connect to home and home culture. 
Communication platforms (e.g. telephony and texting) and social media (e.g. Facebook and Twitter) have global usage with literature in the field fascinated at the ways in which mobile subjects utilise ICT to connect to their networks (Castells 2009) and particularly to home (Hjorth 2011; Gomes, Berry, Alzougool \& Chang 2014). However, the literature is wanting when it comes to the role that media productions (e.g. film, television and music) play in mobility (Gomes and Alzougool 2013). Work in this area is often limited to settled (non-English speaking) migrants, centring around the lack of representation of migrants in the media or migrant stereotypes in the media (Cunningham \& Nguyen 2000; Ang 2006) and the significance of ethnic media on migrants (Ang, Hawkins \& Dabboussy 2008). This paper attempts to start plugging this under-researched area since entertainment media. Media studies, cultural studies and audience studies scholars have long argued the significance of the media in influencing and shaping society’s culture. Entertainment media, as Hall (1973), Ang (1985), Chopra and Gajjala (2011) and others (Morley 1980; Davis \& Baron 1981; Moores 1993) argue, plays a significant role in transmitting culture through media productions. The international students I interviewed admitted that entertainment media is important to them and that they consume this everyday via the web. However, they also stated that they hardly watch any Australian films or listen to any local music, with only a few noting that they sometimes watch local television. Instead they consume the kind of entertainment they watched and listened to back in their homeland, which is predominantly American.

Regardless of the country participants come from, entertainment media allows for a subliminally active and continuous sense of belonging to the home nation through familiarity of content, the display of home culture, familiarity of characters and players, familiarity of language and so on (Martin, Lewis \& Sinclair 2013). Entertainment media is an avenue which allows participants the opportunity to replicate aspects of their everyday lives in the home country to the host nation. Work on migrants and the media for instance indicate that migrants enjoy consuming entertainment media from their homeland because they are able to identify with the productions. Cunningham and Nguyen (2000) point out that the Vietnamese migrants they spoke to watched Hong Kong (martial arts) films, particularly those featuring Jackie Chan, as well as Vietnamese films and television shows, and listened to New Wave Vietnamese music (which includes Vietnamese cover versions of English songs). Lewis and Hiranon (2000) observe that watching Thai media productions allowed the Thai diaspora who came to Australia in the 1980s and 1990s a form of sense of cultural identification. 
The international students interviewed admitted to connecting to their homeland through their choice of entertainment. Participants noted that they often watched films that were in the same culture or language as them, viewed television shows from their home nation and listened to music in their ethnic language. It is worth noting that while the participants may have stated that they watched films from the culture or language, these films may not necessarily be from the home country, for example a film in the Chinese language of Mandarin may be from Taiwan rather than from China. The participants also consumed entertainment products outside their cultural and language groups. About half stated that they watched films from outside their cultural and language groups, while a smaller number did so when it came to television shows. Only a few participants stated that they listened to music other than English or their native language. Participants who consumed media that was not in English and not in their native language did so because this is what they already consumed in their home nation. Such music was exclusively Korean or Japanese - the two most popular entertainment industries in Asia. The popularity of the Japanese and Korean pop culture industries among Asian international students is not surprising. J-Pop and Korean Wave have had a foothold in Asia for the past few decades and their cultural impact across Asia has been the subject of serious academic concern (Chua 2012; Jung 2011). The international students continue appreciating this association with their favourite entertainment industries and actively maintain cultural links to the homeland in this way (Gomes \& Alzougool 2013).

Almost all the international students declared a preference for American-made English-language film, television and music productions. The American domination of the entertainment market for international students is not surprising since America exports its entertainment industry on a global scale. These American productions are meant primarily for North American audiences but because of the power of the USA's global distribution machinery, global audiences become familiar with and identify with American culture as seen in the replication of American culture in the everyday life of its global audience, for example,. the adoption of hip hop culture by Malay youth in Singapore (Kamaludeen 2013).

The popularity of American-made English-language productions can be read as a result of transnational flows as theorised by Appadurai (1996). In his pioneering work on defining globalisation, Appadurai (1996) is cautious about interpreting the global flows he describes in his work on the spread of technology and media as being American-centric. However, while Appadurai was writing his theories in the early days of scholarship on globalisation, the ensuring years have clearly seen the domination of American culture through the media. It is 
predictable then that when international students live overseas they look for the same kind of entertainment they have been used to in their home nations.

While entertainment media allows participants to connect to their homeland while at the same time practising a form of cultural diversity in their choices of entertainment products, the same cannot be said in regard to their consumption of Australian media. Although all participants had lived in Australia for a minimum of three months, with the majority having spent a year or more here, very few admitted to engaging with local entertainment. Australian entertainment is not at all popular with international students, with only a few stating that they watched some Australian television and almost no student admitting to watching local films or listening to Australian music. When asked why they did not engage with local entertainment, participants cited the lack of knowledge of Australian culture and the difficulty they have with the Australian accent as reasons why domestic productions were not appealing to them. Meanwhile those who watched Australian television confined their viewing to transnational franchised reality shows such as the local versions of The Voice Australia (2012-present) and Masterchef. (2009-present) Those who watched these television shows stated that they were competitions about generic non-Australian specific content. The Voice for instance features familiar popular global American hits which the international students would be familiar with regardless of the country they were living in since participants admitted that they usually download such music or listen to it online. Meanwhile, Masterchef features competitive culinary skills in a familiar format and an array of international cuisine.

The most interesting responses I received during the interviews with the students was their lack of awareness about the Australian multicultural and multilingual television channel SBS. Almost all the participants had never heard of SBS, much less watched or listened to any of the multicultural and multilingual programs that this station offers. While SBS programing offers television shows, online television content, films, music and news all in the various Asian languages that the international students speak or are familiar with (e.g. a Malaysian student who likes Japanese anime), , their preference was almost always for the commercial channels. In addition, the international students stated that if they did watch Australian television, they would prefer to see (white) Australians rather than multicultural faces. As a male postgraduate student from India explains: 
I’m in Australia I would expect Australian...[white]...faces here.-If I wanted to see Indian faces, I’d go back to India.

For this student, he expects to see Caucasians in the media because that is not only what he understands Australia to be but what he expects to also see, at least in the media. Perhaps the Asian international students interviewed preferred seeing white faces on television because they perceive "real" Australians to be white/Caucasian, which I discussed earlier in this paper.

\section{Conclusion}

This paper thus unpacks the parallel society Asian international students occupy through an examination of their social networks and entertainment media consumption. Here I present an intricate picture of international students who turn to familiar experiences that reflect their circumstance (as international students) and background (nationality, culture and language) in order maintain a sense of their everyday life during their Australian stay. Through in-depth interviews with 47 Asian international student participants in Melbourne, this study brings to light the fact that international students principally identified themselves according to their status as foreigners studying in Australia and had social networks that were made up of fellow international students mostly from their home nation as well as from Asia. These social networks helped international students by providing community support while living a transient life in a foreign nation. The international students also admitted that they had very few or no local friends and found it difficult to identify with both “Australians” and Asian-Australians (and their concerns), thus making it difficult for them to feel "at home” in Australia, other than through international student networks. To complicate matters, the participants in this project generally considered Australians to be exclusively white/Caucasian rather than ethnically diverse.

While participants did not consider Australians to have a multicultural makeup, they considered their social networks to be multicultural precisely because members are international students regardless of whether they come from Asia or elsewhere. Finally this research also reveals that international students are not one dimensional but diverse actors whose individual tastes in the entertainment media is also reflective of their cultural diversity. This cultural diversity though is rooted in the consumption of transnational entertainment products (film, television and music) which many were already consuming in the home nation. While some of these entertainment productions came from the home nation and from other parts of the Asian region, the 
majority came from America (e.g. Hollywood). This diversity however does not include Australian-made productions, which unfortunately leads to a further lack of (cultural) connection to the host nation.

When discussing migrant diversity and multiculturalism in Australia, the focus often is on Australian citizens, diversity through generations of migration and first generation migrants from non-English speaking backgrounds. This is not surprising since migrants who have become citizens and permanent migrants have actively chosen Australia as their adopted new homeland with the intention of both contributing to and benefitting from Australian society, culture and economy. There has been little attention though on international students when discussing multiculturalism in Australia. While international students are transient, it may be necessary to start including them as part of the conversation on migrant diversity and multiculturalism. This is because international students contribute to the Australian economy through onshore exportation of the education industry and its related secondary industries (e.g. building and tourism) and by joining the casual and sessional workforce (e.g. retail and hospitality), and because of their significant numbers, they are a visible and important sector of the Australian community.

\section{Acknowledgement}

I would like to thank the three anonymous reviewers for their time and valuable feedback. 


\section{References}

Abelmann, Nancy. 2009. The Intimate University: Korean American Students and the Problems of Segregation. Durham: Duke University Press.

Anderson, Benedict. 1983. Imagined Communities: Reflections on the Origin and Spread of Nationalism. London: Verso.

Ang, Ien. 1985. Watching Dallas: Soap Opera and the Melodramatic Imagination. London: Methuen.

Ang, Ien. 2006. Living Room Wars: Rethinking Media Audience for a Postmodern World. London: Routledge.

Ang, Ien, Gay Hawkins and Lamia Dabboussy. 2008. The SBS Story: The Challenge of Cultural Diversity. Sydney: UNSW Press.

Anand, Prem. 2007-present. The Noose, Television series. Singapore: Mediacorp.

Appadurai, Arjun. 1996. Modernity at Large: Cultural Dimensions of Globalization. University of Minneapolis: Minnesota Press.

ABS (Australian Bureau of Statistics). 2011. "International Students.” Available from: http://www.abs.gov.au/ausstats/abs@.nsf/Lookup/4102.0Main+Features20Dec+2011 [Accessed 13 October 2013].

ABS. 2013. “Australian Social Trends, July 2013.” Available from: http://www.abs.gov.au/AUSSTATS/abs@.nsf/Lookup/4102.0Main+Features20July+2013\#p6 [Accessed 21 July 2014].

ABS. 2012. “2011 Census Reveals One in Four Australians is Born Overseas”. Available from: http://abs.gov.au/websitedbs/censushome.nsf/home/CO-59 [Accessed 25 August 2014].

ABS. 2014. "Overseas Arrivals and Departures, Australia, May 2014.” Available from: http://www.abs.gov.au/ausstats/abs@.nsf/productsbyCatalogue/568BCE24A5E5CEC5CA257774001A BE30?OpenDocument [Accessed 20 July 2014].

AEI (Australian Education International). 2013a. "Monthly Summary of International Student Enrolment Data - Australia - YTD August 2013.” Available from: https://aei.gov.au/research/International-StudentData/Documents/Monthly\%20summaries\%20of\%20international\%20student\%20enrolment\%20data\% 202013/08_August_2013_MonthlySummary.pdf

[Accessed 22 November 2013].

AEI . 2013b. "Research Snapshot: International student numbers 2012." Available from: https://aei.gov.au/research/Research-

Snapshots/Documents/International\%20Student\%20Numbers\%202012.pdf [Accessed 20 July 2014].

ATC (Australian Trade Commission). 2014a. “Education Costs in Australia.” Available from: http://www.studyinaustralia.gov.au/global/australian-education/education-costs [Accessed 20 July 2014].

ATC. 2014b. "Scholarships to Study in Australia." Available from: http://www.studyinaustralia.gov.au/global/australian-education/scholarships [Accessed 20 July 2014].

ATC. 2014c. "Work while you Study.” Available from: http://www.studyinaustralia.gov.au/global/live-inaustralia/working [Accessed 20 July 2014]. 
Castells, Manuel. 1997. The Power of Identity, The Information Age: Economy, Society and Culture Vol. II. Cambridge, MA; Oxford, UK: Blackwell.

Castells, Manuel. 2009. Communication Power. Oxford and New York: Oxford University Press.

Chang, S., B. Alzougool, M. Berry, C. Gomes, S. Smith and D. Reeders. 2012. "Communicating with International students: How do their social networks impact on where they go to for information?” Conference Proceedings of the 23rd ISANA International Education Conference, 4-7 December 2012, ISANA International Education Association, 1-10. Available from: http://events.cdesign.com.au/ei/viewpdf.esp?id=314\&file=//srv3/events/eventwin/docs/pdf/isana2012fi nal00032.pdf [Accessed 3 March 2014].

Chau, W. 2010. “International Students: Are They a New and Emerging Community?” Australian Mosaic 24:17-18.

Chopra, Rohit and Radhika Gajjala. 2011. Global Media, Culture, and Identity: Theory, Cases, and Approaches. Oxford and New York: Routledge.

Chua, Beng Huat. 2012. Structure, Audience and Soft Power in East Asian Pop Culture. Hong Kong University Press.

City of Melbourne. 2013. “International Students.” Available from: https://www.melbourne.vic.gov.au/communityservices/foryouth/internationalstudents/Pages/Internatio nalstudents.aspx [Accessed 23 November 2013].

Cunningham, S. and T. Nguyen. 2000. “Popular media and the Vietnamese diaspora”. In Floating Lives: The Media and Asian Diasporas: Negotiating Cultural Identity through Media, edited by S. Cunningham and J. Sinclair, 91-135. St. Lucia, Queensland: University of Queensland Press.

Davis, D.K. and S. J. Baron. 1981. “A History of Our Understanding of Mass Communication.” In Mass Communication and Everyday Life: A Perspective on Theory and Effects, edited by D.K. Davis and S.J. Baron, 19-52. Belmont: Wadsworth Publishing.

de Mol, John, Jr. creator. 2012-present. The Voice Australia, Television series. Australia: Network Nine.

Delanty, Gerard. 2003. Community: Key Ideas. London: Routledge.

Department of Immigration and Border Protection. 2014. “Work conditions for Student visa holders.” Available from: http://www.immi.gov.au/students/students/working_while_studying [Accessed 20 July 2014].

Department of Social Services. 2014. “The People of Australia - Australia’s Multicultural Policy”. Settlement and Multicultural Affairs. Available from: http://www.dss.gov.au/our-responsibilities/settlement-andmulticultural-affairs/publications/the-people-of-australia-australias-multicultural-policy [Accessed 20 July 2014].

Fozdar, Farida, Brian Spittles and Lisa Hartley. 2014. “Australia Day, Flags on Cars and Australian Nationalism”. Journal of Sociology 31 March. Available from: http://jos.sagepub.com/content/early/2014/03/31/1440783314524846?papetoc [Accessed 20 July 2014].

Giddens, Anthony. 1981. A Contemporary Critique of Historical Materialism. Berkeley and Los Angeles: University of California Press.

Giddens, Anthony.1991. Modernity and Self-Identity: Self and Society in the Late Modern Age. Cambridge: Polity. 
Gomes, C. and B. Alzougool. 2013. “Transnational Citizens and Identities: International Students' SelfPerceived Identities, their Social Networks and their Consumption of Entertainment Media in Australia”. Conference Proceedings of the 24th ISANA International Education Conference, 3-6 December 2013, 1-15. Available from: http://proceedings.com.au/isana/docs/2013/Gomes_Catherine.pdf [Accessed 13 March 2014].

Gomes, C., M. Berry, B. Alzougool, and S. Chang. 2014. "Home Away From Home: International Students and Their Identity-Based Social Networks in Australia”. Journal of International Students 4 (1): 2-15.

Gomes, Catherine. 2014. "Xenophobia online: unmasking Singaporean attitudes towards 'foreign talent' migrants”. Asian Ethnicity 15 (1): 21-40.

Gudykunst, W. B., G. Gao, S. Sudweeks, S. Ting-Toomey and T. Nishida. 1991. "Themes in opposite sex, Japanese-North American relationships”. In Cross-cultural interpersonal communication, edited by S. Ting-Toomey and F. Korzenny. Newbury Park, CA: Sage.

Hage, G. 1998. White Nation; Fantasies of White Supremacy in a Multicultural Society. New York: Routledge.

Hall, S. 1973. Encoding and decoding in the television discourse. Centre for Contemporary Cultural Studies, University of Birmingham.

Harrison, D. 2010. "Residency Lures Foreign Students". The Age, 15 February. Available from: http://www.smh.com.au/national/education/residency-lures-foreign-students-20100214-nzks.html [Accessed 3 October 2013].

Hendrickson, B., D. Rosen and R.K. Aune. 2011. “An Analysis of Friendship Networks, Social Connectedness, Homesickness, and Satisfaction Levels of International Students.” International Journal of Intercultural Relations 35 (3): 281-295.

Hjorth, L. 2011. “A Case Study on Mobility, Home and Being Away in Shanghai”. In Mobile Technologies and Place, edited by R. Wilken and G. Goggin, 140-156. London \& New York: Routledge.

Hjorth, L. \& M. Arnold. 2012. Online@AsiaPacific: Networked Sociality, Creativity and Politics in the AsiaPacific Region. New York: Routledge.

Jakubowicz, A. and K. Seneviratne. 1996. “Ethnic Conflict and the Australian Media.” Making Multicultural Australia. Available from: http://www.multiculturalaustralia.edu.au/doc/jakubowicz_3.pdf [Accessed 3 November 2013].

Jung, Sun. 2011. Korean Masculinities and Transcultural Consumption. Hong Kong University Press.

Kamaludeen, M. N. 2011. “Representing Hip-hop in Singapore: A Study of the Malay Youth”. ARI Seminar Series, 18 October 2011, Asian Research Institute, National University of Singapore.

Kashima, E. \& E. Loh. 2006. “International students’ Acculturation: Effects of International, Conational, and Local Ties and Need for Closure”. International Journal of Intercultural Relations 30: 471-485.

Kashima, E. \& D. Pillai. 2011. “Identity Development in Cultural T\transition: The Role of Need for Closure”. Journal of Cross-Cultural Psychology 45 (5): 725-739.

Koleth, Elsa. 2010. "Multiculturalism: A Review of Australian Policy Statements and Recent Debates in Australia and Overseas”. Parliament of Australia, Research Paper no. 6 2010-11. Available from: http://www.aph.gov.au/About_Parliament/Parliamentary_Departments/Parliamentary_Library/pubs/rp/ rp1011/11rp06 [Accessed 20 July 2014]. 
Kudo, K., and K. A. Simkin. 2003. "Intercultural Friendship Formation: The Case of Japanese Students at an Australian University”. Journal of Intercultural Studies 24: 91-114.

Lewis, G. and C. Hiranon. 2000.”'Mi arai mai mai mai?’ Thai-Australian Video Ways”. In Floating Lives: The Media and Asian Diasporas: Negotiating Cultural Identity through Media, edited by S. Cunningham and J. Sinclair. 1-34. St. Lucia, Queensland: University of Queensland Press.

Martin, F, T. Lewis and J. Sinclair. 2013. "Lifestyle Media and Social Transformation in Asia”. Media International Australia 147: 51-61.

Moores, Shaun. 1993. Interpreting Audiences: The Ethnography of Media Consumption. London: Sage.

Morley, David. 1980. The 'Nationwide' Audience: Structure and Decoding. London: BFI.

Nadarajah, Yaso, Martin Mulligan, Supriya Singh and Chris Chamberlain. 2014 (forthcoming). “Introduction”. In Searching for Community: Melbourne to Delhi, edited by Supriya Singh, Yaso Nadarajah, Martin Mulligan and Chris Chamberlain, 13-28. New Delhi: Manohar Publishers \& Distributors.

Portes, A. \& DeWind, J. 2004. “A Cross-Atlantic Dialogue: The Progress of Research and Theory in the Study of International Migration”. The International Migration Review 38 (3): 828-851.

Rattansi, Ali. 2011. Multiculturalism: A Very Short Introduction. Oxford and New York: Oxford University Press.

Robertson, S. 2013. Transnational Student Migrants and the State: The Education-Migration Nexus Transnational Student-Migrants and the State. UK: Palgrave-Macmillan.

Roddam, Franc, creator. 2009-present. Masterchef Australia, television show. Australia: Network Ten.

Ryan, Peter. 2005. 'Apologise to Blainey’. The Australian: 10.

Sawir, E., S. Marginson, A. Deumert, C. Nyland and G. Ramia. 2008. "Loneliness and International Students: An Australian Study”. Journal of Studies in International Education 12: 148-180.

Soutphommasane, Tim. 2012. Don't Go Back Where You Came From: Why Multiculturalism Works. NSW: NewSouth Publishing.

Stratton, J. 1999. "Multiculturalism and the Whitening Machine, or How Australians Become White”. In The Future of Australian Multiculturalism: Reflections on the twentieth anniversary of Jean Martin's The Migrant Presence, edited by Hage and R. Couch. Sydney, NSW: University of Sydney: 163-188.

Student Services, The University of Melbourne. 2014. "Financial Aid.” Available from: http://services.unimelb.edu.au/finaid/planning/cost_of_living/summary [Accessed 20 July 2014].

Urry, John. 2000. Sociology Beyond Societies: Mobilities for the Twenty-First Century. Oxford \& New York: Routledge.

Yamazaki, M., N. Taira, N. Shun-ya, \& T. Yokoyama. 1997. "The role of ethnicity in the development of the Asian students' attitudes toward Japanese and other cultures”. Japanese Journal of Educational Psychology 45: 119-128.

Yang, Peidong. 2014. “Foreign Talent”: Desire and Singapore’s China Scholars. PhD thesis. Oxford: St. Cross College.

Ying, Y. W., 2002. "Formation of cross-cultural relationships of Taiwanese international students in the United States”. Journal of Community Psychology 30 (1): 45-55. 
${ }^{1}$ While Australia is also host to students on exchange/study abroad, this paper does not include them under the banner of 'international students'. International students in this paper are full-fee paying students. In other words, their education in Australia is not subsidised by the Australian government as it is for local students. Largely international students fund their education in Australia through private means. Some students might be funded by scholarships from their home nations or by Australian programs such as the Australian Agency for International Development (AusAID) and International Postgraduate Research Scholarships (IPRS) scholarships.

2 The term 'overseas student' was used more frequently in the 1980s and 1990s before the current term 'international student'.

${ }^{3}$ There are official organisations such as Australian Education International (AEI) and International Education Association Inc. (ISANA) committed to improving the welfare of international students through policy and research together with sectors of local government dedicated to 'enhanc[ing] the wellbeing and experience of life for international students in Melbourne' (City of Melbourne 2013).

${ }^{4}$ Australia famously abolished its White Australia Policy in 1973. This policy dictated a preference for migration from certain European countries, particularly Britain.

${ }^{5}$ Since the late 2000s, these discussions have increasingly included asylum seekers.

${ }^{6}$ All English-language courses are aimed at international students where English is not their primary language.

${ }^{7}$ Both Malaysia and Singapore are similar multicultural nations which support Chinese, Malay and Indian ethnic groups as well as a shared British colonial history

${ }^{8}$ The terms are derived from Mandarin and Cantonese respectively and are often used in other places which support a Chinese diaspora such as Malaysia, Taiwan and Hong Kong. However, the terms are not limited in use to ethnic Chinese but as in Singapore are part of everyday usage by the different ethnicities in these places. 